\title{
Diversity Among Construction Professionals: A Study of Their Perception of Construction Site Management Practices
}

Olanipekun Ayokunle Olubunmi

Department Of Quantity Surveying,

Federal University Of Technology,

Akure, Nigeria

olanipekun1439@yahoo.com
Aje Isaac Olaniyi

Department Of Quantity Surveying,

Federal University Of Technology,

Akure, Nigeria

aje_niyi2002@yahoo.com

\author{
Adedokun Fisayo \\ Department Of Quantity Surveying, \\ Federal University Of Technology, \\ Akure, Nigeria \\ fisayoadedokun@gmail.com
}

DOI 10.5592/otmcj.2014.2.3

Research paper

\section{Keywords}

Site management practices, Construction Professionals, Perception, Interests, Diversity
INTRODUCTION: THIS PAPER TESTS A PROPOSITION THAT THERE IS NO SIGNIFICANT DIFFERENCE IN CONSTRUCTION PROFESSIONALS' PERCEPTION OF CONSTRUCTION SITE MANAGEMENT PRACTICES IN THE CONSTRUCTION INDUSTRY.

Purpose: The purpose of this paper is to provide support, or otherwise to the diversity attribute of the construction industry. The construction industry is largely regarded as diverse; however, the industry also manifests signs of alignment especially on issues that tie construction professionals to project goals. One of such issues is construction site management, which when effective, leads to project success.

Design: This paper adopts a survey research design where wellstructured questionnaires were used in obtaining the perception of construction professionals (architects, civil engineers, builders and quantity surveyors) on their prioritisation of construction site management practices. The data obtained was subjected to empirical analysis that informed the findings.

Findings: The research proposition is rejected. Significant difference exists in the construction professionals' perception of construction site management practices in the construction industry.

Value: The findings of this paper is valuable to tinkering the need for professionals' interests and goal alignment in the construction industry

Research Limitation/Implication: Interview case study could be deployed to complement the survey research design used. The singular survey design used is not however expected to undermine the findings owing to the comprehensiveness of the questionnaire designed and the scientific basis (objective-oriented) upon which the respondents were selected. - 
Practical Implication: The paper informs on the non-unified interests that exist among professional service providers in the construction industry.

\section{INTRODUCTION}

It is a common theme in the construction management literature that the construction industry is diverse. One of the reasons for this position is that different construction professionals have to come together, even with dissimilarities in their background, training and exposure, to deliver project goals (Almahmoud and Doloi, 2013). More so, to achieve the goals of a typical construction project, more than one construction professional is involved (Chinyio and Olomolaiye, 2010). Thus

Depending on the type and nature, different construction professionals are involved in construction projects. For instance, in complex building project, the services of architects, engineers, quantity surveyors, builders are important. In a typical bungalow project, only the services of architects or civil engineers may be required. Also in a developing country like Nigeria, it is constant to have architects, civil engineers, builders and quantity surveyors as primary construction professionals on contracted building projects. Other professionals such as services engineer may be commissioned as well but not in all cases. Whatever the mix of construction professionals on different projects, each has its own its own interest, especially in the exercise of their skills and judgement (Abdul-Rahman, Wang and Yap, 2010).

It is also known that construction professionals commissioned on construction projects are tied to the goal of successful project delivery, especially in terms of cost, time and quality (Bowen et al., 2012; Federal Republic of Nigeria, 2006). This suggests a shared area of interest among the professionals. That is, despite the diversity of different construction professionals, achieving project goal is an interest they all shared. Therefore with this, does it hold true that the construction industry is diverse? In another way, are the interests of different construction industry professionals significantly different from one another, especially in their perception of issues?

This paper answers these questions by testing a proposition, that there is no significant difference in construction professionals' perception of construction site management practices in the construction industry. Construction site management involves a combination of activities, which turn basic resources into a finished product (Jimoh, 2012; Mohamed and Anumba, 2006). Further, effective construction site management enhances productivity on construction sites (Jimoh, 2012), which leads to project success (Hammad, Omran and Pakir, 2011). Therefore as a variable of project success, construction site management can be regarded as a shared area of interest among construction professionals.

The setting of this research is the Nigerian construction industry, where the perceptions of architects, civil engineers, builders and quantity surveyors on construction site management were obtained and analysed based on the methodology devised. According to Equality and Human Rights Commission (2011), the construction industry is showing green shoots of delivering on diversity. Therefore the outcome of this research is significant to the success of the construction industry.

Perception based researches are not uncommon in construction. The researches of Windapo and Martins (2010), Chileshe and Yirenkyi-Fianko (2011), Chiocha, Smallwood and Emuze (2011) and Yirenkyi-Fianko and Chileshe (2012) are all perception based in varying aspects of construction. Owing to ineffectiveness in some site management practices (poor construction supervision and unsustainable building construction practices) resulting into building collapses in Nigeria, Agwu (2013) specifically carried out perception survey in her six major cities, which led to the proffered solutions. This research rests on this basis to proffer conclusions and recommendations on the subject area.

\section{Literature review}

Construction site, management and practices

Construction site is a factory for the production of building project (ILO Construction, 2000). That is, it is where the plans of construction professionals are realised, in accordance with the client's needs. According to Jimoh (2012), construction work is more complex technically, thereby requiring robust administrative solutions. In other words, construction site management, which is the organisation of the materials, labour and other resources on the site (Mohamed, 2006; Mohamed and Anumba, 2006) is an important consideration on construction sites. Also construction site management is important to achieving productivity on construction sites as well as mitigating rework, defects, delays, disputes and cost overruns on construction projects (Durdyev and Mbachu, 2011; Hammad, Omran and Pakir, 2011; Su, 2010; Odusami, Oyediran and Oseni, 2007). Thus, the success of construction projects depend on the effectiveness of the construction site management applied (Elbeltagi, 2001). However, there are practices that must be applied to ensure effective construction site management practices (Jimoh, 2012). These practices (identified and described below) are fundamental integrating process used to achieve organised and purposeful results in the area where building or construction work is being carried out (Santos, Powell and Sarshar, 2002). These practices have implications for 
construction professionals, whose goal is to deliver construction project to cost time, quality and other added requirements by the client. That is, it is in the interest of construction professionals that construction sites are effectively managed so as to fulfill project goals. In line with (Jimoh, 2012; Mohamed, 2006), the six construction site management practices are described below:

1. Management, Supervision and Administration of sites: This is the arrangement on construction sites that lends to effective information dissemination and exchange. Information such as correspondences, minutes, RFIs, labour allocations, payroll, progress reporting, notices or claims, instruction, drawing register and technical information does flow among stakeholders, for processing and further actions during and after project construction. Thus it is a management practice on construction sites.

2. Commercial Management: This is setting up of a cost control system designed to enable the site management team to satisfactorily collect and produce information from which the monitoring of actual costs can be compared to estimated costs. This covers estimating, valuations, interim payment, variations, dayworks, cost-value reconciliation, final accounts and cash flow. In Nigeria, Quantity Surveyors are hugely involved in commercial management but not without the input of other professionals like architects and engineers.

3. Legal, Health and Safety Management: The key to success on construction sites are to ensure that health and safety aspects are carefully considered and the risk of danger and hazard to persons, as a result of site activities, is systematically safeguarded. Effective health and safety management is founded on the provision of a safe and healthy working environment with safe systems of work at its core. As a site management activity, health and safety management on the construction site are guarded legally using safety policy, insurance, building regulations, British Standards, and Codes of Practice.

4. Planning, Monitoring and Control: This construction site management practice is the process of determining, analysing, devising and organising all resources necessary to undertake construction project. It also includes monitoring and controlling the planned actions towards successful project delivery. Some of the specific activities include the production of a Gantt-chart, network analyses, method statements, resource levelling, progress reports and exception reports.

5. Delivery and Materials' handling: This construction site management practice deals with resources management on construction sites, particularly pertaining to materials and plants. It involves the management of deliveries and their subsequent handlings site in terms of requisitions, purchase orders, materials call off and plant returns etc. There are four types of information considered useful for the delivery and materials' handling site management practice: the specification, contract drawings, the bill of quantities, and architect's instruction issued during construction. The production of these information are distinctly the responsibilities construction professionals.

6. Production On-site and Off-site: This site management practice deals with the application of quality procedures to production on-site and off-site as a means of enhancing quality levels and reducing defects. Examples of activities supporting production include quality assurance plans and report, contract terms, drawings, specifications, setting-out and measurement. Quality assurance focuses upon consumer protection and offers clients an assurance that the building has been built properly under satisfactory conditions of quality controls and that the building has been judged suitable for its intended use.

\section{Interest of construction}

professionals in construction site management

Above, it is seen that effective construction site management (practices) is in the interest of construction professionals, especially to mitigate technical problems and ensure productivity. Thus construction site management is a common area of concern; or an area of shared interest for construction professionals. However, in the literature, construction professionals are perceived to have different interests especially during construction project execution (Abdul-Rahman, Wang and Yap, 2010; Chinyio and Olomolaiye, 2010). It is said that most of the construction professionals' differences manifest in the course of exercising their skills and judgement, in which case is during construction process. In fact, Zhang et al. (2013) state that such differences lead to high level of fragmentation among professionals in the construction industry. Thus with an aspect of construction such as construction site management practice where construction professionals have shared interest, it appears it is uncertain the diversity in the construction industry. In short, it remains a research issue to ascertain the level of diversity among construction professionals. Before that, the roles of the architects, civil engineers, builders and quantity surveyors on construction sites are described below. They serve as a pointer to their interests in construction site management (Hussin and Omran, 2009).

\section{Architect}

Anyanwu (2013) points out two roles of Architect which are linked to site activities. First, the architect helps the 
client to formulate his requirements in an understandable form, bearing in mind any statutory conditions that may apply. In the process of formulating client's requirements, site characteristics are inculcated, especially since site conditions are different for different projects and locations. This could be in form of proper demarcation of constructed area from on-site production area. It would be counterproductive to be batching and mixing concrete where the building is going to stand. , The second is during the construction stage where the architect visits the site periodically for inspections to ensure that in general, the work being carried out on site is incompliance with architectural design and specifications. This is another important role of Architect that is significant for construction site management. It serves as check and balance to earlier plans by the Architect and other stakeholders. In sum, architects have roles on construction site, which in turn, is important to construction site management.

\section{Civil Engineer}

The roles of civil engineers are related to the architects'. Civil engineers' produce drawings, specifications, schedules and other relevant data that may be required for the overall design of the project, and they do visit the site periodically for inspections to ensure that in general, the work being carried out is in compliance with their engineering drawings, schedules and specifications (Anyanwu, 2013). In civil engineering projects, civil engineers' roles are much more extensive. They include analysis of maps, drawings, blueprints, aerial photography and other topographical information, designing of hydraulic systems and structures following strictly construction codes, calculating load and grade requirements, liquid flow rates and material stress points to ensure that the structure can withstand stress, ensuring construction safety in its entirety and surveying the land before construction begins to ensure that there are no impediments in the way of where the structure will be built (Hussin and Omran, 2009). Taken together, these roles are either performed on-site, or for the site. In both cases, civil engineers' roles are important to construction site management.

\section{Builder}

The unique roles of Builders are preparing: the buildability and maintainability report, the project quality management plan, the project health and safety plan, programming construction works, managing the construction process and specifying materials and workmanship (Obiegbu, 2009). Preparing buildability and maintainability report ensures that the construction becomes easy and simple as possible, reduces waste, such as excessive cutting of components, maximum use of site plant leading to increased productivity. The programme of work preparation helps to establish the method to be used for construction on site (method statement) while the quality management plan provides information on operations and to serve as a reference manual for site personnel. The safety management plan details the procedures of establishing safety culture on the construction site, and including statement on the welfare provisions on site, the first aid facilities and how to attend to an accident in event of any occurrence. Managing the construction process is about dynamics of the construction in order to achieve specified quality standards, and this includes ensuring on-site, and/or off-site implementation of all the project monitoring and control documents. In essence, builder roles are important to construction site management. The material handling and specification ensure that specifications are met on the site. Majority of these roles of Builders are site based while the others are linked to sites, one way or another.

\section{Quantity Surveyor}

Quantity Surveyors are professionals concerned with the cost and contract management of construction projects (Maarouf and Habib, 2011). The roles of Quantity Surveyors include controlling construction costs by accurate measurement of the work required, achieved by the application of expert knowledge of costs and prices of work, labour, materials and plant required (Anyanwu, 2013; Hussin and Omran, 2009). This role is significant to construction planning where the focus is on optimal resource utilisation. That is, what, when and how resources come, and how they are utilised on-site. In short, it is significant to construction site management.

\section{Research proposition}

This research proposed that there is no significant difference in construction professionals' (architects, civil engineers, builders and quantity surveyors) perception of construction site management practices in the construction industry. In Nigeria, it is only these professionals that are constantly involved in different types of construction projects, thus their choice for this research. The methodology described below was followed in testing this proposition.

\section{Research methodology and}

profile of respondents

The survey research method was adopted in this paper. The target population was professional service providers in the construction industry- architects, civil engineers, builders and quantity surveyors who have been practicing on or before 2009 in Ondo State of Nigeria. Ondo is a State in the South Western part of Nigeria, and it was not until 2009 when the current administration was ushered in that construction activities increased drastically. Since then and till date, Ondo State is being described as an abode of construction and construction sites. Thus in arriving at the respondents for 
this study, a preliminary survey was conducted to identify the construction professional service providers in the state that had been practicing on or before 2009 in the State. The reason is to assure that professionals responding to questions on construction site management practices had been on ground before or during the period when construction site activities increased. 112 construction professional service providers (22 Architects, 20 Quantity Surveyors, 39 Civil Engineers and 31 Builders) were identified and administered questionnaires. The cross-sectional survey was conducted between June and December 2013 with the majority of the questionnaires administered to the identified professionals in their offices (32 government offices, 42 private offices) and the rest 38 on different construction sites. During the period, 81 questionnaires representing $72 \%$ of the distributed were retrieved. Ten were however found unsuitable for analysis.

In developing the questionnaire used in the collection of primary data, prior studies of both Mohamed (2006) and Jimoh (2012) were reviewed and used. Therein, the following were the site management practices (management, supervision and administration of sites; commercial management; legal, health and safety management; planning monitoring and control; production on-site and off-site). Consequently, the questionnaire was designed based on the goal of the current research as well as findings from the review of literature. The questionnaire contained structured close ended questions, but divided into two sections. Section one was designed to elicit information on the personal profiles of the respondents while the section two dwelt basically on construction site management practices. Respondents were provided with options of different practices identified in the literature and were asked to identify on a 5-point Likert scale which according to their perception should be accorded top priority in the management of construction sites.

In line with the goal of this research, which is to test the proposition, whether significant difference exists in the perception of construction site management practices, mean score was initially used in analysing the data obtained in a segmented manner different professionals. This allowed for the determination of the rankings accorded by different professions to different construction site management practices. Where two or more variables have the same mean score, they are ranked equally, and the next ranking is skipped so that the last ranking is equal to the number of variables. Mean scores indicate the average level of agreement with an item and a mean score for each item can be generated by assigning values to all non-missing item responses and then averaging all the response values for that item (NC NOVA, 2008). This was followed by the use of Kendall coefficient of concordance to determine the degree the degree of agreement, and its test statistic $p$-value to determine the significance of the degree of agreement among the construction professionals in their mean score rankings. According to Akadiri (2011), this coefficient (W) provides a measure of agreement between respondents within a survey on a scale of zero to one, with 'o' indicating no agreement and ' 1 ' indicating perfect agreement or concordance. Using the $95 \%$ confidence level, $p$-value less than 0.05 was interpreted to mean a significant Kendall coefficient of concordance (W) value.

The result of the analysis of the profile of respondents reveal 15, 16, 21, 19 architects, quantity surveyors, builders, civil engineers respectively, representing $21 \%, 22 \%, 30 \%$ and $27 \%$ of the total of 71 population. This implies an almost even distribution of the respondents. Table 1 further reveals the highest academic qualification of the respondents, which are divided across the four majorly recognised academic qualifications in Nigeria. 28 respondents have
Bachelor Degree as their highest academic qualification, closely followed by Master Degree of 27 of the respondents. The Doctoral Degree is the least highest academic qualification, with only 4 architects and 1 civil engineer having it. The aggregate of the respondents' academic qualification reveals a high level of academic qualification. The type of organisations where the respondents are working also divided across the Public sector/government, Contracting, Consulting and Developers organisations. 25 of the respondents are engaged in the Public sector, 13 in the Contracting organisations, 26 in the Consulting firms and 7 in the Property developers company. With the variance in respondents' organisations, diverse opinion may be possible considering the differences in the organisations' goals and approaches in construction operations. Emphasis was placed on Ondo State in sampling the opinion of respondents on construction site management and as such, they were asked for their involvement in managing construction sites since 2009. From the result, all the respondents have been involved in construction site management since 2009. It is worthy of note that it was in 2009 that Ondo State started witnessing increased construction activities. Thus, the respondents affirming their involvement in site management over the period mean they have knowledge and by extension, perception on managing construction sites. The result on the profile of respondents is summarised in Table 1.

\section{Result and discussion}

\section{Perception on construction site management practices}

Table 2 has the result of the analysis of the perception of Architects, Quantity Surveyors, Civil Engineers and Builders on the following construction site management practices: management, supervision and administration of sites, commercial management, legal, health 


\begin{tabular}{|c|c|c|c|c|c|}
\hline Professions (frequency/\%) & $\begin{array}{c}\text { Architects } \\
(15 / 21 \%)\end{array}$ & $\begin{array}{l}\text { Quantity } \\
\text { Surveyors } \\
(16 / 22 \%)\end{array}$ & $\begin{array}{l}\text { Builders } \\
(21 / 30 \%)\end{array}$ & $\begin{array}{c}\text { Civil } \\
\text { Engineers } \\
(19 / 27 \%)\end{array}$ & TOTAL \\
\hline \multicolumn{6}{|l|}{ Qualifications } \\
\hline Master & 11 & 6 & 5 & 5 & 27 \\
\hline Doctoral & 4 & & & 1 & 5 \\
\hline Bachelor & & 9 & 10 & 9 & 28 \\
\hline Higher National Diploma & & 1 & 6 & 4 & 11 \\
\hline \multicolumn{6}{|l|}{ Type of Organisation } \\
\hline Public & 4 & 8 & 6 & 7 & 25 \\
\hline Contracting & 7 & 3 & & 3 & 13 \\
\hline Consulting & 4 & 5 & 9 & 8 & 26 \\
\hline Developers & & & 6 & 1 & 7 \\
\hline \multicolumn{6}{|l|}{$\begin{array}{l}\text { Involvement in site } \\
\text { management since } 2009\end{array}$} \\
\hline Yes & 15 & 16 & 21 & 19 & 71 \\
\hline \multicolumn{6}{|l|}{ No } \\
\hline TOTAL & 45 & 48 & 63 & 57 & 213 \\
\hline
\end{tabular}

\section{Table 1. Profile of Respondents}

and safety on construction sites, planning, monitoring and control, delivery and materials' handling and production on-site and offsite.

Architects: The mean scores of responding architects for different construction site management practices $(n=15)$ in ascending order include: management, supervision and site administration (4.73, 1st), legal health and safety $(4.26,2 \mathrm{nd})$, planning, monitoring and control (4.26, 2nd), delivery and materials' handling $(3.80,4$ th), production on-site and off-site $(3.73,5$ th), and commercial management $(3.73,5$ th).

- Quantity surveyors: The mean scores of the responding quantity surveyors for different construction site management practices $(n=16)$ in ascending order include: management, supervision and site administration (4.18, 1st), commercial management (4.12, 2nd), planning, monitoring and control $(4.12,2 \mathrm{nd})$, delivery and materials' handling $(3.87,4$ th), production on-site and off-site $(3.75,5$ th), and legal health and safety $(3.31,6$ th).

Civil engineers: The mean scores of responding civil engineers for different construction site management practices $(n=19)$ in ascending order include: management, supervision and site administration (4.05, 1st), delivery and materials' handling
(3.84, 2nd), legal health and safety (3.73, 3rd), planning, monitoring and control $(3.68,4$ th), production on-site and off-site $(3.63,5$ th), and commercial management $(3.47,6$ th). Builders: The mean scores of responding builders for different construction site management practices $(n=21)$ in ascending order include: legal health and safety $(4.70,1 \mathrm{st})$, management, supervision and site administration (4.60, 2nd), delivery and materials' handling $(4.55,3 \mathrm{rd})$, planning, monitoring and control $(4.40,4$ th), production on-site and off-site $(3.55,5$ th), and commercial management (3.30, 6th). 
Based on the rankings in Table 2 a further analysis (Table 3), was carried out to reveal the construction management practices where the construction professionals' perception contrast or otherwise. It is in form of a matrix where the column indicates profession(s) and the column indicates the construction site management practices. Since there are four professions involved in the research, each profession has eighteen possibilities to either agree or disagree with other professions ( $3 \times 6$ matrix table.). That is, each profession can agree, or disagree with other professions in eighteen possibilities, or share the total possibilities between agreement or disagreement on construction site management practices. In the analysis, ' $x$ ' was used to denote agreement on perception, while ' $\checkmark$ ' was used otherwise. The summation of agreement was calculated to reveal the professional(s) with the most and least agreement on the subject.

In the Table 3 showing the (agreement, disagreement) matrix, architects, builders, quantity surveyors and civil engineers have $(9,9),(5,13),(7,11)$ and $(7,11)$ respectively. This paper carries out further analysis (presented in Table 4), to determine the degree the degree of agreement, and the significance of the degree of agreement in the different construction professionals' mean score values.

In Table 4, the $W$ value is 0.207 , far away from 1.00, the coherence value. Also, the p-value is 0.00 at $95 \%$ significance level.

\section{Discussion of main findings}

In Table 2, all the construction professionals (Architects, quantity surveyors, civil engineers and builders) indicated their perceptions (through the mean scoring) on the priority to be accorded different construction site management practices. This suggests that construction site management is an area of interest to the construction professionals.
The construction site management practice of management/supervision/site administration is the most preferred by architects, quantity surveyors and civil engineers with the highest rankings of (4.73, 1st), (4.18, 1st) and (4.05, 1st) respectively. Also this site management practice is ranked in second position (4.60, 2nd) by the builders after legal, health and safety $(4.70,1 \mathrm{st})$. Since the evolution of alternative procurement systems such as integrated project delivery (IPD), most construction professions have shifted from technicalities only to management orientated practices. In the contemporary construction, it is not uncommon to find any of these professionals providing project management services in addition to technical services. In fact, these construction professionals secure job commissions as managers rather than technical professionals in Nigeria. This would explain the high priority they accord this construction site management practice. It is notable that the quantity surveyors ranked commercial management in second position (mean score $=4.12$ ) . Quantity surveyors primarily provide cost management services on construction projects (Anyanwu, 2013; Maarouf and Habib, 2011), and thus the high priority accorded commercial management. However, production on-site and off-site was ranked lowly in fifth position by all the professionals. This would explain the enormity of construction wastes on contemporary construction sites (see Elbeltagi, 2001).

In Table 3, it could be seen the perceptions of construction professionals are shared between agreement and disagreement on the prioritisation of construction site management practices. In the analysis, out of 72 possibilities for all the construction professionals (e.g. each profession with 18 possibilities multiplied by 4 professions equals 72 ), there are 44 disagreements, and 28 agreements in the perception of construction professionals on the prioritisation of construction site management activities. Except for the architects who have equal times of agreement as disagreement with other professionals on the prioritisation of construction management practices, others disagreed more times with other professionals. Unarguably, the result is skewed in favour of disagreement among construction professions (Table 3). Said differently, each construction profession (e.g. architect, civil engineers, quantity surveyors and builders) disagrees with other construction professionals on prioritisation of construction site management practices. Notably, none of the construction professionals agree on legal, health and safety construction site management practice (Table 3). There are however very limited agreements for other construction site management practices except for production on-site and offsite, where all the construction professionals agree with one another on its prioritisation, though it was ranked lowly.

In Table 4, further empirical analysis carried out supports the results presented on Tables 2 and 3. The Kendall coefficient of concordance $(W)$ value is 0.207 , far away from 1.00 , the coherence value. This implies that the construction professions differ in their perceptions of construction site management practices. The p-value is 0.00 , and since it is lesser than the 0.05 ( $95 \%$ significance level), this means that the differences in the perception of the architects, quantity surveyors, builders and civil engineers is significant. Therefore, the proposition that that there is no significant difference in construction professionals' perception of construction site management practices in the construction industry is rejected. This is in line with the popular position in the construction industry that different construction professionals have different interests either in the construction industry or on particular project (see Abdul-Rahman et al., 2010 Behm, 2008; Farah, 2005; Shapiro, 2005; Too, Betts and Dowdle, 2003 ILO, 2001). 


$\begin{array}{lcccccccccccrrr}\text { Architects } & 15 & 4.73 & 1 & 3.73 & 5 & 4.26 & 2 & 4.26 & 2 & 3.80 & 4 & 3.73 & 5 \\ \begin{array}{l}\text { Quantity Surveyors } \\ \text { Civil Engineers }\end{array} & 16 & 4.18 & 1 & 4.12 & 2 & 3.31 & 6 & 4.12 & 2 & 3.87 & 4 & 3.75 & 5 \\ \text { Builders } & 19 & 4.05 & 1 & 3.47 & 6 & 3.73 & 3 & 3.68 & 4 & 3.84 & 2 & 3.63 & 5 \\ & 21 & 4.60 & 2 & 3.30 & 6 & 4.70 & 1 & 4.40 & 4 & 4.55 & 3 & 3.55 & 5\end{array}$

Table 2. Mean item scores and the ranking of the perception of respondents on construction site management practices

\begin{tabular}{|c|c|c|c|c|c|c|c|c|c|}
\hline \multicolumn{2}{|c|}{ Professional(s) } & \multicolumn{6}{|c|}{ Construction site management practices } & \multicolumn{2}{|c|}{ SUMMATION } \\
\hline & & MSAS & $\mathrm{CM}$ & LHS & PMC & DMH & POO & AGG & DISAGG \\
\hline \multicolumn{10}{|c|}{ Architects } \\
\hline Arch. & Bld. & $x$ & $x$ & $x$ & $\checkmark$ & $\checkmark$ & $\checkmark$ & 3 & 3 \\
\hline Arch. & QS & $\checkmark$ & $x$ & $x$ & $\checkmark$ & $\checkmark$ & $\checkmark$ & 4 & 2 \\
\hline Arch. & C.Eng. & $\checkmark$ & $x$ & $x$ & $x$ & $x$ & $\checkmark$ & 2 & 4 \\
\hline \multicolumn{2}{|c|}{ Sub-total } & & & & & & & 9 & 9 \\
\hline \multicolumn{10}{|c|}{ Builders } \\
\hline Bld. & Arch. & $x$ & $x$ & $x$ & $x$ & $x$ & $\checkmark$ & 1 & 5 \\
\hline Bld. & QS & $x$ & $x$ & $x$ & $x$ & $x$ & $\checkmark$ & 1 & 5 \\
\hline Bld. & C.Eng. & $x$ & $\checkmark$ & $x$ & $\checkmark$ & $x$ & $\checkmark$ & 3 & 3 \\
\hline \multicolumn{2}{|c|}{ Sub-total } & & & & & & & 5 & 13 \\
\hline \multicolumn{10}{|c|}{ Quantity surveyors } \\
\hline QS & Arch. & $\checkmark$ & $x$ & $x$ & $\checkmark$ & $\checkmark$ & $\checkmark$ & 4 & 2 \\
\hline QS & C.Eng. & $\checkmark$ & $x$ & $x$ & $x$ & $x$ & $\checkmark$ & 2 & 4 \\
\hline QS & Bld. & $x$ & $x$ & $x$ & $x$ & $x$ & $\checkmark$ & 1 & 5 \\
\hline \multicolumn{2}{|c|}{ Sub-total } & & & & & & & 7 & 11 \\
\hline \multicolumn{10}{|c|}{ Civil engineers } \\
\hline C.Eng. & Arch. & $\checkmark$ & $x$ & $x$ & $x$ & $x$ & $\checkmark$ & 2 & 4 \\
\hline C.Eng. & QS & $\checkmark$ & $x$ & $x$ & $x$ & $x$ & $\checkmark$ & 2 & 4 \\
\hline C.Eng. & Bld. & $x$ & $\checkmark$ & $x$ & $\checkmark$ & $x$ & $\checkmark$ & 3 & 3 \\
\hline \multicolumn{2}{|c|}{ Sub-total } & & & & & & & 7 & 11 \\
\hline
\end{tabular}

Arch-Architect, Bld.-Builder, QS-Quantity surveyor, C.Eng.-Civil engineer, MSAS-Management/supervision/site administration, CM-Commercial management, LHS-Legal, health and safety, PMC-Planning, monitoring and control, DMH=Delivery and materials' handling, POO-Production on-site and offsite, $x$-disagreement on rankings, $\checkmark$-agreement on rankings, AGG-Summation of agreement, DISAGG-Summation of disagreement.

Table 3. Analysis based on Table 2

\section{Conclusion}

Based on evidences from the literature review, this study proposes that there is no significant difference in construction professionals' perception of construction site management practices in the construction industry. In other to test this proposition, a survey research methodology which involved the use of descriptive statistics and
Kendall coefficient of concordance was adopted. The methodology supports the descriptive nature of this research, and based on the findings, it is concluded that there is diversity among 


\begin{tabular}{|l|c|}
\hline \multicolumn{2}{|c|}{ Test Statistics } \\
\hline $\mathrm{N}$ & 71 \\
\hline Kendall's W & \\
\hline Chi-Square & .207 \\
\hline Df & 72.520 \\
\hline Asymp. Sig. & 5 \\
\hline
\end{tabular}

Table 4. Kendall Coefficient of Concordance $(W)$ test

construction professionals, especially in their perception of the prioritisation of construction management practices. Theoretically, this conclusion supports the multidisciplinary nature of the construction industry. The industry is diverse, where different construction professionals with diverse backgrounds and trainings come together to achieve construction goals. Practically, this conclusion further exposes the subsisting differences among construction professionals within the construction industry. That is, among architects, quantity surveyors, builders and civil engineers, a holistic view of the construction industry, or an aspect of it is yet impossible.

\section{Recommendations}

Based on the conclusion of this paper, the following recommendations are made:

1. The differences in the perception of the construction professional stakeholders mean poor interest alignment. This has a negative influence on construction project delivery. Therefore this knowledge is recommended for construction clients so as to introduce an interest-alignment program as part of procurement process for the different construction professionals commissioned on their projects.

2. The Equality and Human Rights Commission Document (2011) reveals that the construction industry is showing green shoots of delivery on diversity. This suggests that the construction industry is capitalising on its diverse nature. In line with this notion, and the conclusion of this research, all the construction industry stakeholders (policy makers, construction professional bodies, construction regulatory bodies, organised clients, contractors, consultants and the Academia) should explore means of directing the industry's diversity to advantage.

\section{References:}

Abdul-Rahman, H., Wang, C. \& Yap, X.W. (2010), How Professional Ethics impact Construction Quality: Perception and Evidence in a fast Developing Economy. Scientific Research and Essays, 5(23), 3742-3749.

Agwu, M.O. (2013), Perception Survey of Poor Construction Supervision and Building Failures in Six Major Cities in Nigeria. British Journal of Education, Society and Behavioural Science, 4(4), 456-472.

Akadiri, O.P. (2011). Development of a MultiCriteria Approach for the Selection of Sustainable Materials for Building Projects. A Doctoral Thesis submitted to the University of Wolverhampton, UK (Published).

Almahmoud, E. \& Doloi, H. (2013), Analysis of Stakeholders' Influence on Construction Processes using Social Network Analysis. Being a paper presented at the Construction, Building and Real Estate Research Conference of the Royal Institution of Chartered Surveyors held in New Delhi, India in association with the University of Ulster and IIT Delhi, 1oth12th September.

Anyanwu, C.I. (2013), The Role of Building Construction Project Team Members in Building Projects Delivery. Journal of Business and Management, 14(1), 30-34.

Behm, M. (2008), Construction Sector. Journal of Safety Research, 39, 175-178.

Bowen, P.A., Hall, K.A., Edwards, P.J., Pearl, R.G. \& Cattell, K.S. (2012), Perceptions of Time, Cost and Quality Management on Building Projects. The Australian Journal of Construction Economics and Building, 2(2), 48-56.

Chileshe, N. \& Yirenkyi-Fianko, A. (2011), Perceptions of Threat Frequency and Impact on Construction Projects in Ghana: Opinion Survey Findings. Journal of Construction in Developing Countries, 16(2), 115-149.

Chinyio, E. \& Olomolaiye, P. (2010), Construction Stakeholder Management. A John Wiley \& Sons, Ltd., Publication, West Sussex, United Kingdom.

Chiocha, C., Smallwood, J. \& Emuze, F. (2011), Health and safety in the Malawian construction industry. Acta Structilia, 18(1), 68-80.

Durdyev, S. \& Mbachu, J. (2011), On-site Labour Productivity of New Zealand Construction Industry: Key Constraints and Improvement 
Measures, Australasian Journal of Construction Economics and Building, 11 (3) 18-33.

Elbeltagi, E. (2001), Construction Site Layout Planning. Retrieved on 13 January, 2014 from http://drahmedelyamany.weebly.com/ uploads/7/o/1/o/7010103/site-layout_ dremad.pdf

Farah, T. (2005), Review of Current Estimating Capabilities of the $3 \mathrm{~d}$ Building Information Model Software to support Design for Production/Construction. A Master Degree thesis submitted to the faculty of the Worcester Polytechnic Institute.

Federal Republic of Nigeria (2006), National Building Code, 1st edition. LexisNexis Butterworths, South Africa

Hammad, M.S., Omran, A. \& Pakir, A. (2011), Identifying ways to improve Productivity in the Construction Industry. Acta Technica-Bulletin of Engineering, 4, 47-49.

Hussin, A. \& Omran, A. (2009), Roles of Professionals in the Construction Industry. Being a paper presented at the International Conference on Economics and Administration, Faculty of Administration and Business, University of Bucharest, Romania ICEA - FAA Bucharest, 14-15th November.

International Labour Organisation (2001), The Construction Industry in the Twenty-first Century: Its Image, Employment Prospects and Skill Requirements. Retrieved on 31 January, 2014 from http://www.ilo.org/ public/english/standards/relm/gb/docs/ gb283/pdf/tmcitr.pdf

International Labour Organisation Construction OS\&H (2000), Construction OS \& H Welfare \& project site. Retrieved on 13 January, 2014 from http://www.ilo.org/wcmsp5/groups/ public/---ed_dialogue/---sector/documents/ presentation/wcms_161896.pdf

Jimoh, R.A. (2012), Improving Site Management Practices in the Nigerian Construction Industry: The Builders' Perspective. Ethiopian Journal of Environmental Studies and Management, 5 (4), 366-372.

Maarouf, R. \& Habib, R. (2011), Quantity surveying role in Construction Projects - A comparison of roles in Sweden and the UK. Retrieved on 31 January, 2014 from http://dspace.mah.se/ bitstream/handle/2043/13533/Thesis\%20 Rabie $\% 20 \% 26 \% 20$ Riad.pdf?sequence $=2$

Mohamed, S.F. (2006), Improving Construction Site Management Practices through
Knowledge Management. A Doctoral Degree (online) thesis submitted to the Loughborough University.

Mohamed, S.F. \& Anumba, C.J. (2006), Potential for improving Site Management Practices through Knowledge Management, Construction Innovation: Information, Process, Management, 6 (4), $232-249$.

NC NOVA (2008), Scoring and Score Interpretation Tool for the NC NOVA “Provider Readiness Assessment Tool. Retrieved on 18 January, 2013 from http://www.ncnova.org/upload/ doc/scoring_tool_for_nc_nova_assessment_ tool.pdf

Obiegbu, M.E. (2009), Unique Roles of Professional Builders in the Society. Being a paper presented at the One day Seminar organized by the Rivers and Bayelsa States Chapter of the Nigerian Institute of Building held at Porthacourt, Nigeria on the 18th November.

Odusami, K.T., Oyediran, O.O. \& Oseni, A.O. (2007), Training Needs of Construction Site Managers. Emirates Journal for Engineering Research, 12 (1), 73-81.

Santos, A. D., Powell, J. A. \& Sarshar, M. (2002), Evolution of Management Theory: The Case of Production Management in Construction. Management Decision, 40 (8), 788-796.

Shapiro, B. (2005), Inherent Conflicts in the Construction Industry and the Structure of Contracts. Being a paper presented at the Conference 'The Fundamentals of Construction Contracts: Understanding the Issues' held in in Vancouver, BC, February 10.

The Equality and Human Rights Commission Report (2011), Equality and Diversity, Good Practice for the Construction Sector. Retrieved on 12 January 2014 from http://www. equalityhumanrights.com/uploaded_files/ research/ed_report_construction_sector.pdf

Too, E., Betts, M. \& Dowdle, D. (2003), A Framework for Construction IT Education. In Proceedings CIB W89 BEAR Conference 2003, Salford, UK.

Windapo, A. \& Martins, O. (2010), An Investigation into Nigerian Property Construction Companies' Perception of Critical Risk. Insurance Markets and Companies: Analyses and Actuarial Computations, 1 (1), 78-83.

Yirenkyi-Fianko A. B. and Chileshe N. (2012) Job Satisfaction of Professionals within the Ghanaian Construction Industry In: Smith,
S.D (Ed) Proceedings of the 28th Annual ARCOM Conference, 3-5 September 2012, Edinburgh, UK, Association of Researchers in Construction Management, 589-599.

Zhang, P., Lingard, H., Blismas, N. Wakefield, R. \& Kleiner, B. (2013), Application of Q-Methodology in studying Construction Stakeholders' Perceptions of OSH Risks An introduction to the Preliminary Stage. Retrieved on 31 January, 2014 from http:// www.conference.net.au/cibwbc13/papers/ cibwbc2013_submission_327.pdf 